\title{
Political Machine and Challenger Victory in a Javanese Village Chief Election ${ }^{1}$
}

\author{
Wegik Prasetyo $^{2}$
}

Received: 5 March 2019 | Accepted: 30 November 2019 | Published: 24 December 2019

\begin{abstract}
Political machines are widely evident in Indonesian elections, particularly in the sale of political services and use of clientelistic strategies. However, in several cases candidates have created political machines without buying political services or employing clientelistic strategies. Using a qualitative approach to examine the 2018 village chief election in Ngestiharjo, Yogyakarta, this article explains how electoral challengers can use political machines without buying political services, as well as the reason such challengers and their machines decide not to employ clientelism in their search for electoral victory. The author shows that several factors, including elite fragmentation, candidate recruitment, socio-political networks, and the existence of a shared enemy effectively nullify the buying of political services and the use of clientelistic strategies. This article shows that local village contexts, as well as reliance on social bonds, enable challengers to avoid the transactionalism and clientelism that have long characterised political machines. This is further supported by the ability of a challenger and his socio-political network to exploit the weaknesses of the incumbent.
\end{abstract}

Keywords: Village Elections, Challenger Victory, Political Machine, Clientelism

\section{Introduction}

At the village level, electoral democracy has been practiced in Indonesia for centuries, from when supporters clashed (Lombard, 1996) or fought with sticks (Kartodirdjo, 1992) to show their support for a favoured village candidate. Since Indonesia began its political reform in 1998, and as widespread democratisation and

1 Research for this article was conducted by the Research Center for Politics and Government (PolGov), Department of Politics and Government, Faculty of Social and Political Sciences, Universitas Gadjah Mada, in conjunction with the Australian National University, Australia, and KITLV, Netherlands. Field research was conducted over the course of one month in ten villages in Bantul, Kulon Progo, and Gunung Kidul Regency, Yogyakarta. The names of informants have been disguised for this article.

2 Researcher at the Research Centre for Politics and Government (PolGov), Department of Politics and Government, Faculty of Social and Political Sciences, Universitas Gadjah Mada. 
decentralisation have occurred, village elections have begun using ballots. Studies have shown that, as with presidential and local elections, village elections now involve extensive brokerage networks and vote buying (Aspinall \& As'ad, 2015; Yuningsih \& Subekti, 2016; Aspinall \& Rohman, 2017). At the same time, many studies have shown how village-level political machines serve to advance the interests of their candidates. This study explores such political machines, defined as political organisations and groups that mobilise support by providing material goods and services in exchange for votes, as they were used in the 2018 village chief elections. The author seeks to understand how political machines can function without transactionalism and clientelism, even in contexts where such things are expected. Using the case of the Ngestiharjo Village Election in Yogyakarta, the author will identify how such political machines function at the village level — the smallest administrative unit in the Indonesian government. ${ }^{3}$

Studies of political machines have predominantly linked them with two things, namely the purchase of political services from machine owners (Gosnell, 1933; Krebs, 2005; \& Golosov, 2013) and the use of clientelism (Stokes, 2005; Gans-Morse, Mazzuca, \& Nichter, 2013; Szwarcberg, 2015); both characteristics are heavily rooted in the economic aspects of political machines. However, these studies tend to ignore the social basis of political machines, which enables them to function without transactionalism and clientelism. The author thus seeks to explain how such political machines support challengers' campaign activities, relying not on economic factors but on social ones. The social support received by challengers is strongly influenced by local contexts, including incumbents' failures, elite fragmentation, challenger candidacy, and socio-political networks. As such, this research does not only identify the factors that contribute to the creation of political machines, but

The author would like to express his gratitude to Dra. Ratnawati, SU, for guiding him through the completion of this study. 
also how village dynamics influence electoral processes.

Political machines are commonly characterised by the use of money to purchase political services as well as by the use of clientelistic strategies such as vote buying. Most owners of political machines offer to a means of creating support through transactional politics and the creation of group benefits (Krebs, 2005; Gans-Morse, Mazzuca, \& Nichter, 2013; Golosov, 2013; Szwarcberg, 2015). Such practices are widespread among electoral candidates and political machines at all levels (Erb \& Sulistiyanto, 2009; Choi, 2011; Aspinall \& Sukmajati, 2015). Candidates and political machines both understand how these strategies can be used to secure voter support and consolidate power. At the same time, voters-particularly those with limited economic means-prefer direct benefits over programmatic politics and long-term policies. This suggests that there is a link between political machine creation, strategy use, and voter orientation during elections.

The case discussed in this article is quite atypical, not reflecting the general tendencies and characteristics of political machines. Generally, political machines require significant financial resources to organise and implement (Farrell, 1996; Krebs, 2005; Budi, Sukmajati, \& Prasetyo, 2018). Within village chief elections, expenditures are exacerbated by two factors. First, Indonesia's village electoral system requires candidates to run independently, rather than with the backing of a political party. Consequently, these candidates lack a solid political machine - if they have one at all (Budi, Sukmajati, \& Prasetyo, 2018). ${ }^{\mathrm{A}} \mathrm{S}$ such, independent candidates tend to purchase the political services that they require to gather voter support. Second, challengers face the significant challenge of overcoming the incumbent advantage (Krebs, 1998; Ansolabehere \& Snyder, 2002; Trounstine, 2011). In general, incumbents - in this case, village chiefs - have a greater opportunity to become elected as they have the resources and networks necessary to practice transactionalism or intimidation. Village chiefs have the authority to control village bureaucracy and budget, an authority which they can 
exploit to increase their own popularity and electability. With these resources and authorities, incumbent village chiefs have significant advantages over their challengers.

To investigate how challengers organise and utilise political machines to defeat incumbents in village elections, the researcher conducted field observations in Ngestiharjo Village between 8 October and 21 October 2018 (seven days before and seven days after the election). This was important not only to ensure easy access to data, but also to ensure that the author gained residents' trust and understood political issues. The author conducted indepth interviews with eight key actors to understand the political machines and linkages used by the challenger, and also spoke with village residents, campaign staff, academics, and the candidates. Informants were selected through snowball sampling, with more informants being selected over time as more information became available.

By examining the case of Ngestiharjo, the author contributes to the literature on political machines by providing an example that does not rely on transactionalism and clientelism. The author asks two questions to understand this phenomenon: how do challengers organise and utilise political machines without buying political services from their owners? How did the challenger and his political machine avoid the practice of clientelism in Ngestiharjo's village election? By answering these questions, this article seeks to contribute a new understanding of how political machines function within village elections.

The author argues that political machines are not always activated through financial means, and that clientelism is not always used to guarantee electoral victory. This study finds that the challenger did not purchase political services, but rather was approached by the owner of the political machine and asked to contest the election; it was this individual who covered the majority of the campaign costs. Furthermore, the challenger also used his existing socio-political linkages, which were untouched by those of 
the incumbent. These socio-political networks were integrated with the political machine to support the challenger's electoral victory. Because such socio-political networks existed outside the political machine, its owner was unable to practice clientelism during the village elections.

This article is divided into six sections. First, the author provides a conceptual discussion of political machines and their use in elections. Second, the author provides a general overview of Ngestiharjo Village and its elections. Third, it discusses the elite fragmentation in Ngestiharjo, particularly as linked to the challenger's campaign. Fourth, the author discusses how the political machine was organised and implemented, as well as how socio-political linkages helped the challenger defeat the incumbent. Fifth, it explains why clientelistic practices such as vote buying were not employed by the challenger. Sixth, the author concludes that political machines are not always associated with the purchase of political services and the practice of clientelism. It may be influenced by such conditions as elite fragmentation, candidate recruitment, socio-political networks, and a shared enemy.

\section{Political Machines and Elections}

Political machines are important elements of elections around the world. Definitions generally fall into two categories. First, political machines are identified with political parties and other political organisations that work effectively to achieve electoral victory. Usually, such organisations have strong and effective leadership, as well as high levels of discipline and authority. The effectiveness of such organisations depends heavily on their leaders' ability to consolidate, maintain, and practice political power. When so defined, political machines are neutral, mere parts of broader political parties or organisations (Gottfried, 1968). Usually owned by elites with massive and loyal support bases, such political machines are used to mobilise voters in support of specific candidates. 
According to Golosov (2013), political machines have complex hierarchal structures, being controlled by bosses, supported by local businessmen, and activated through networks of electoral workers.

Second, the term political machine may also refer to political parties and political organisations that utilise material resources to gather voter support and win elections. Under such a definition, the effectiveness of political machines cannot be separated from their clientelistic strategies and exchange of government services for votes (Banfield \& Wilson, 1966). This produces what Gosnell (1933) terms "plunder politics", a situation in which political machines seize control of government and public services and use this control to maintain their power. On the other hand, Krebs (2005) associates political machines with the provision of public goods in return for voter mobilisation. In such a situation, a transactional relationship is created between the politician using the political machine and the voters who receive these goods. When understood thusly, political machines are viewed negatively, perceived as undemocratic, detrimental to social order, and promoting corruption.

From these definitions, it can be seen that political machines have two key characteristics: structural and stylistic. Structurally, political machines consist of authoritative leaders and obeisant followers, who are connected within a hierarchy; leaders exert control over their followers during electoral contestations. Stylistically, meanwhile, political machines utilise specific clientelistic strategies and government instruments to mobilise voters. In electoral contestations, political machines often link politicians with voters either through direct exchange or indirect exchange.

Political machines are frequently created where there is a perceived need for exchange between individuals (voters) and politicians (vote-seekers) as they seek to access or maintain power. Political machines enable candidates to provide material benefits (particularly financial incentives) to voters in exchange for their support. According to Hedman (2010), money is the fuel upon which the political machine runs, as it is not only used to acquire 
political services and undertake political activities, but also used in clientelistic practices. According to Gans-Morse et al. (2013), political machines employ at least four clientelistic strategies: vote buying, turnout buying, abstention buying, and double persuasion. In developing countries, clientelistic practices have proven an effective means of influencing voters; Stokes (2005), for example, shows that political machines are effectively used to buy the votes of poor Argentinians. Poor people (persons with limited income, education, and housing quality) are 65 times more likely to sell their votes than people whose needs are met. According to Szwarcberg (2015), political machines focus on buying the votes of people who lack the bargaining power to oppose their activities as well as people who share resemblances with candidate and/or machine.

The literature has generally associated political machines with the buying of political services and the practice of material-based clientelism. As such, this article applies a different perspective, distinguishing it from other studies of political machines. First, the author shows that the buying of political services is not an integral part of political machines; where political machines are derived from social bonds, it can be avoided. The rise of challengers, the existence of socio-political networks, and the presence of a shared enemy also contribute. The existence of significant socio-political networks enables candidates to avoid the practice of clientelism, as political machines' owners are restricted when candidates' existing networks enjoy significant bargaining power.

\section{The Socio-Political Context of Ngestiharjo}

To better understand how the political machine promoted the challenger's electoral victory in Ngestiharjo, the author will first describe the socio-political conditions of the village. Although located in the predominantly rural Bantul Regency, Ngestiharjo is a predominantly urban village, a situation that can be attributed to its location within the Yogyakarta Ring Road and on the border of 
Yogyakarta City. Being located within the buffer zone, Ngestiharjo has experienced rapid physical development. Such projects, including road and drainage canal construction, received $42 \%$ of the village's 2017 budget (APBDes Ngestiharjo 2017). This physical development cannot be separated from the massive influx of capital from housing developers, restauranteurs, and other investors (DR, interview, October 2, 2018). ${ }^{4}$ Owing to its strategic location, as well as ready access to major thoroughfares, Ngestiharjo is seen as having significant investment potential.

One such investor played a significant role in Ngestiharjo's 2018 village election, being the owner of the political machine that supported the challenger. Two elements must be considered. First, in terms of structure, this investor was the owner and leader of the political machine. A resident of Ngestiharjo, he had founded the Indonesian Red-White Movement (Gerakan Merah Putih Indonesia, GMPI) to channel his political ambitions and aspirations. Meanwhile, stylistically, he employed clientelist strategies to influence nine elections, including the 2002 Ngestiharjo village chief election, the 2012 Ngestiharjo village chief election, the 2014 Bantul legislative election, the 2014 Yogyakarta provincial legislative election, the 2014 Indonesian legislative election, the 2014 Regional Representative Council election, the 2014 presidential election, the 2015 Bantul local election, and the 2015 Ngestiharjo village election (CS, interview, October 31,2018$){ }^{5}$

This political machine had a significant interest in the 2018 Ngestiharjo village election for two reasons. First, the owner of the political machine, being a property speculator, required continuous access to land in the village. Second, the owner of the political machine needed his candidate to win the election to prepare voters for the 2019 legislative election. The challenger in the village election

\footnotetext{
4 Interview with the Village Secretary of Ngestiharjo.

5 Interview with the owner of the political machine.
} 
was a "proposal", a trailblazer opening the way for a later legislative candidate. $^{6}$

Several other actors had their own interests in Ngestiharjo's village election. First, political parties. Although village candidates and campaigns are not formally backed or conducted by parties, in practice these parties are directly and indirectly involved in elections (Yuningsih \& Subekti, 2016). Parties support candidates, fund their campaigns, and help plan and implement strategies. Parties become involved in village chief elections because most of their constituents live in villages; access to villagers during village elections can be translated to access during other elections.

Ngestiharjo has long been a stronghold of the Partai Demokrat Indonesia - Perjuangan (Democratic Party of Indonesia - Struggle, PDIP) in Bantul. In elections, including local, legislative, and presidential, PDIP regularly receives the majority of villagers' votes. Even in the 2015 local election, when PDIP's candidate Sri Surya Widati was defeated by Gerindra's Suharsono, PDIP still won Ngestiharjo (KPU, 2015). Likewise, in the 2014 legislative election, PDIP dominated Bantul Constituency 6 (an area that includes Ngestiharjo Village) (KPU, 2014). Several other parties, recognising PDIP's dominance, have attempted to undermine its authority through village elections. At the same time, there have been internal tensions; several PDIP cadres have taken non-party positions during local and legislative elections, ultimately becoming serious opponents after being excommunicated from the party (SL, interview, November 1, 2018). ${ }^{7}$

Second, village administrators. It is public knowledge that, despite neutrality being required by law, village administrators tend to favour either the incumbent or the challenger. Incumbents use their power to intimidate village administrators into supporting

\footnotetext{
6 Ibid.

7 Interview with a key PDIP figure and cadre in Ngestiharjo.
} 
them. Administrative staff who fail to support the incumbent find themselves marginalised and excluded from village activities. Such administrators are more likely to support the challenger (DR, interview, October 2, 2018). ${ }^{8}$ Gaining the favour of village administrators is important, as these people have significant influence on the local community.

Third, the villagers themselves. Of all the actors involved, it is the people themselves whose interests should be advanced and promoted. Fundamentally, elections are constitutional means of choosing new leaders and of evaluating existing leaders' performance.

\section{History of Village Elections in Ngestiharjo}

When Ngestiharjo held its first election in 2002, the political machine backed Purwono, who emerged victorious over a former village administrator and three other candidates. In backing and supporting Purwono, the political machine did not function on its own; in worked in conjunction with PDIP, the dominant political party in the village. Purwono was a member of this party, serving as the chairman of its Ngestiharjo Branch, and this party actively supported him. Of the election's five candidates, most of whom were entrepreneurs and administrators, Purwono was the youngest and the least experienced. However, he was still respected for his family background; he was the grandson of a former village chief and son of a civil servant, and thus considered part of the village's upper crust (HP, interview, October 9,2018$).{ }^{9}$ His kinship networks, prestige, and connection with PDIP facilitated the political machine's efforts to bring about his electoral victory.

The owner of the political machine took charge of Purwono's campaign team, and thus could easily control its activities, including

\footnotetext{
8 Interview with the Village Secretary of Ngestiharjo.

9 Interview with the Chairman of PDIP's Kasihan District Office.
} 
its undemocratic activities and its violations of electoral law. This machine, which consisted mostly of youths and local strongmen, intimidated the supporters of other candidates, stationing members outside these candidates' offices. Their presence instilled a sense of fear in their opponents, which they retained even as they attempted to consolidate their power. Ultimately, other candidates' campaign teams stopped meeting, bending in the face of such intimidation (EL, interview, October 4, 2018). ${ }^{10}$

Second, the owner of the political machine practiced vote buying by systematically distributing money to voters. Voters were visited on the morning of the election and provided money, as well as a piece of paper on which Purwono's name and candidate number was written; such a practice is commonly known as "serangan fajar" (dawn attack). In this manner, they sought to interest voters in supporting Purwono (SL, interview, November 1, 2018). ${ }^{11}$ Third, the owner of the political machine paid officials at local ballot boxes to damage otherwise valid votes for Purwono's opponent. When an election official showed a ballot to the witness, he or she would prick it with a small needle. A large number of ballots were rendered invalid in this manner. ${ }^{12}$

The owner of the political machine was able to take such measures because he had the necessary financial capital, thanks in part to his successful property speculation. The author does not have any specific data on how many electoral laws were violated during the 2002 election, but voters' stories indicate that the strategies used were similar to those used in local and legislative elections.

PDIP also played a very important role in Purwono's electoral victory. Ngestiharjo has long been a stronghold of the party, which has branches down through the village level. Purwono's close links with PDIP's Ngestiharjo Branch helped him mobilise voters at the

\footnotetext{
10 Interview with a Ngastiharjo Village Aide.

11 Interview with a key PDIP figure and cadre in Ngestiharjo.

12 Ibid.
} 
village level. The Chairman of PDIP's Ngestiharjo Branch knew that Purwono had been a dedicated party member since the 1990s, and thus used the party's networks to consolidate support for the candidate. Over his ten years as village chief (2002-2012), Purwono continued to consult with PDIP about government programmes, using the local branch as a think tank in his planning activities (HP, interview, October 9, 2018). ${ }^{13}$

In 2010, two years before Purwono's second term concluded, the former chairman of PDIP's Ngestiharjo Branch (now the chairman of PDIP's Kasihan District Office) asked Purwono to name his successor. The chairman recommended that Purwono name his wife, Oni Oktavani, as this would enable Purwono to maintain control of the village treasury. Purwono himself, meanwhile, would prepare to contest Bantul's 2014 legislative election. To support this idea, the chairman of PDIP's Kasihan District Office called for voters to meet with Purwono and convince him to agree with this plan. He hoped that, with Purwono in Bantul's parliament and Oni as village chief, the party would have a solid base in Ngestiharjo. ${ }^{14}$

To prepare for Oni's candidacy, the Chairman of PDIP's Kasihan District Office created Komunitas Peduli Rakyat (Concerned People's Community, PERAK) as a political vehicle for improving her popularity and electability. PERAK advocated for the poor and helped them access healthcare and education, using the political backing of its sponsor to bypass related government institutions. In 2011, Oni began to be involved in all of PERAK's activities, particularly its visits with villagers, during which attendees were told that they needed to vote for Oni in the 2012 election if they still desired PERAK's support. PERAK's health and education programmes were well-received by villagers, and this enabled the organisation to brush aside claims of identity and dynasty politics. ${ }^{15}$

\footnotetext{
13 Interview with the Chairman of PDIP's Kasihan District Office.

14 Ibid.

15 Ibid.
} 
Oni Oktavani won the 2012 village chief election with 55\% of the vote. Of the three candidates contesting the election, Oni was the only female candidate, and the only one not born in Ngestiharjo. The other two candidates were local-born men; Surojo was a former village administrator and university lecturer, while Solahudin was the takmir of the local mosque. In this election, the political machine used the same campaign team and clientelistic strategies; likewise, it continued to rely on PDIP for support. Overall, the electoral victories of Purwono and Oni in 2002 and 2012 (respectively) stemmed from the effective use of clientelism by their political machines and their political party.

Many villagers felt disappointed by Oni's leadership, including the owner of the political machine as well as several village administrators. She was seen as arrogant, authoritarian, unjust, and pilihsih, ${ }^{16}$ and as such many of her former backers chose to withdraw their support. After she identified administrators who had voted against her in the 2012 election, Oni had them "relieved of duty". She also withheld financial and administrative assistance from pedukuhan (sub-village administrative units) where she had received little electoral support (DR, interview, 2 October 2018). ${ }^{17}$

Such issues were exacerbated by the widespread practice of extortion, known locally as palagara, ${ }^{18}$ after the new village law was passed. Although the 2014 Village Law firmly forbade public servants from demanding financial recompense for their services, villagers were required to pay money (identified as 'contributions to the village treasury') before they could acquire land certificates, buy/ sell land, or receive permits; Oni would not sign until this money

16 Pilihsih is a local abbreviation of the phrase pilih kasih (to play favourites, i.e. to favour particular people or territories over others).

17 Interview with the Village Secretary of Ngestiharjo.

18 Palagara is a local term referring to an amount of money paid to village administrators to ensure that they are willing to facilitate land sales. The practice of palagara has existed for centuries, and been passed from generation to generation. The amount paid is determined through negotiations between village residents and administrators. 
was paid. The amount demanded varied, being agreed upon by Oni and the person seeking her assistance, but it was generally $10-15 \%$ of the total value of the transaction/venture. Corrupt practices were also evident in the hiring of village administrators and the filling of other village offices; for example, to become head of $d u k u h$ (the leader of a pedukuhan), one was expected to pay Rp 30-50 million into the village coffers. Such rumours and practices were capitalised upon by the challenger and his team in the 2018 village election (DR, interview, October 2, 2018). ${ }^{19}$

\section{Elite Fragmentation: The Beginning of the End of a Political Dynasty}

Unlike in Ngestiharjo's 2002 and 2012 elections, the political machine did not support Oni during the 2018 election. The owner of the political machine, disappointed by Oni and Purwono's performance, decided to find another candidate, one he deemed capable of defeating Oni in the election. This situation was exacerbated by personal issues. One day, after the election, the owner of the political machine heard Purwono say "aku ora dadi anggota dewan, ora patheken" (if I weren't elected, no biggie). ${ }^{20}$ The owner of the political machine believed that this statement failed to recognise his hard work as campaign manager.

Second, although Purwono and Oni had received electoral support, they were unwilling to support the owner of the political machine when he experienced financial distress. In 2014, the owner of the political machine lost a significant amount of money in land speculation, forcing him to pawn many of his assets. At around this time, his wife was diagnosed with breast cancer, and thus required expensive treatments. The owner of the political machine thus

19 Interview with the Village Secretary of Ngestiharjo.

20 Patheken is used to express the view that one would not mind losing or not having something. This word was used by Soeharto when he resigned from the presidency in 1998 . 
asked Purwono and Oni to accelerate the administrative processes necessary for him to pawn his land. However, neither village chief agreed. Ultimately, the owner of the political machine had to handle his own certificates and permits before ultimately pawning his assets. Once he was able to regain his assets, and after his wife entered remission, the owner of the political machine chose not to support either candidate (CS, interview, October 31, 2018). ${ }^{21}$

Third, the village residents often blamed Oni for their difficulty accessing village services and development programmes under her leadership. Oni's performance was disparaged, with residents citing her administration's widespread practice of extortion (palagara), lack of neutrality (pilihsih) in village development, and limited budget transparency. For this, the owner of the political machine was blamed, as he and his team had promoted Oni. ${ }^{22}$

Owing to these three factors, fragmentation occurred among the village elites. The owner of the political machine withdrew his support for Oni and sought a new candidate, one who could challenge her. Purwono and Oni had created a political dynasty through their party identity and access to economic resources, and this had enabled them to rule the village for more than fifteen years. They and their favoured elites controlled the village government at various levels, while their opponents were marginalised. Such elite fragmentation contributed significantly to the fall of the PurwonoOni dynasty.

In July 2018, the owner of the political machine happened upon Fathoni, who had approached him in search of funding for a Bantul-level Bregada Cultural Festival. ${ }^{23}$ Seeing Fathoni's expressions and manner of speech as he explained his proposal, the owner of the political machine was convinced that Fathoni had the spirit of a

21 Interview with the owner of the political machine.

22 Ibid.

23 Bregada (literally 'brigade') refers to the soldiers of the Yogyakarta Sultanate. The Bregada Festival is held annually to preserve this militaristic art and ensure regimental discipline. 
leader. Furthermore, Fathoni's significant experience leading village activities (including prayer groups and youth contests) made him even an even more enticing candidate.

The owner of the political machine urged Fathoni to run for village chief, and offered both material and immaterial support for this campaign. As part of the courting process, he told Fathoni about his own political experiences as well as his success during elections from the village level (as in the case of Puwono and Oni) to the national level (having won Ngestiharjo for Joko Widodo in the 2014 election). The owner of the political machine also discussed the political and government conditions in the village, including the lack of transparency, continued practice of extortion, and corruption that plagued the village administration. He tried to persuade Fathoni to contest the election, and after considerable consideration, contemplation, and discussion, both with the owner of the political machine and with other societal leaders, Fathoni agreed. However, they did not initially agree upon any specific division of labour, funding, or plans for after the election. Such aspects of the campaign were only decided afterwards.

Ngestiharjo's 2018 election was contested by three candidates, namely the incumbent Oni Oktavani and the challengers Agus Feriyanto and Fathoni Aribowo. The main difference between the 2018 election and the previous village elections (i.e. the 2002 and 2012 elections) was the candidate the owner of the political machine. Where he had previously backed Purwono and Oni, in 2018 the owner of the political machine supported the challenger Fathoni. Recognising this shift, Oni rethought her own electoral strategies (HP, interview, October 9, 2018). ${ }^{24}$ On the last day of registration, she withdrew the documents that she had submitted to the electoral committee; this left a single candidate, Fathoni. As such, pursuant to village election law, the registration period was

24 Interview with the Chairman of PDIP's Kasihan District Office. 
extended for twenty days. ${ }^{25}$

During this extended registration period, Oni, Purwono, and the chairman of the PDIP's Kasihan District Office registered Agus Feriyanto as a 'puppet candidate'. This decision was influenced by two factors. ${ }^{26}$ First, Oni and her team worried that Fathoni would withdraw his candidacy, thereby leaving Oni as the sole candidate. If this were to happen, the election only be held after the next legislative election, in 2020, and an acting village chief would be appointed by the leaders of Kasihan District; Oni's team feared this possibility. Second, they hoped that Agus' background in youth organisations would divide Fathoni's voter base. This was clearly evident in the photographs and slogans used in Agus' campaign material, which borrowed Fathoni's characteristic peci (skull cap) and slogans of change. Third, Agus was Purwono's nephew (despite living in a nearby village) and an active member of PDIP's Kasihan District Office.

During the extended registration period, Oni registered her candidacy the day before she registered Agus. After submitting her documents, Oni used her power and authority as incumbent to visit various parts of the village and provide residents with material assistance and incentives. Using village funds and facilities, she facilitated trips to Bali and Bandung (deemed 'comparative study tours') for the village advisory council, as well as local administrators, welfare activists, farmers, and women. She also purchased tractors for farmers, provided cookware to street vendors, made uniforms for the Family Welfare Empowerment (Pemberdayaan Kesejahteraan Keluarga, PKK) group, and gave foodstuffs to pedukuhan where she enjoyed significant support (DR, interview, October 15, 2018). ${ }^{27}$

However, this provision of individual and club goods did

25 Bylaw No. 8/2017 regarding the Termination and Appointment of Village Chiefs requires elections to be contested by at least two candidates.

26 Ibid.

27 Interview with the Village Secretary of Ngestiharjo. 
not correlate positively with voter support. She was unable to escape her poor performance as village chief, including her lack of transparency and her favouritism in programme distribution. This was compounded by her poor campaign performance. During rallies, she was unable to show her positive achievements or her plans for the future. Fathoni, meanwhile, spent three days providing a detailed overview of his vision, mission, and programmes, while simultaneously attacking the shortcomings of the incumbent. The "puppet candidate" Agus, meanwhile, only presented a normative vision, mission, and programme. All of these contributed to Fathoni being recognised as the better candidate.

Ultimately, Fathoni won the election, which was held on 14 October 2018 and saw a voter turnout of $73 \%$. He received $48.2 \%$ of votes, edging out the incumbent (who received $46.6 \%$ of the votes); Agus, the "puppet candidate", received only $5.2 \%$ of votes. The fact that Fathoni only won the election with a slight margin, despite the support of the political machine, shows that PDIPwhich continued to back Purwono, Oni, and the bureaucracy they had controlled for fifteen years-remained influential. Meanwhile, Fathoni was able to optimize his resources, including the political machine, party networks, and political linkages to reach voters and gain support.

\section{The Political Machine and Challenger's Socio-Political Networks}

To understand Fathoni's electoral victory, particularly his ability to quickly amass voter support, it is necessary to understand how the challenger organised the political machine and utilised his socio-political networks. After meeting with the owner of the political machine and agreeing to contest the election, Fathoni decided to activate his socio-political networks, finding allies who had not been compromised by the incumbent. For this, Fathoni relied on his kinship networks. He cited two reasons for this (Fathoni 
Aribowo, interview, October 30, 2018). First, Fathoni did not entrust the campaign to the owner of the political machine, recognising that it was in no condition to win an election. Second, Fathoni sought to protect himself from the dominance and control of the political machine's owner, both during elections and afterwards. The owner of the political machine, a property speculator with significant interest in the 2019 legislative election, had a vested interest in the village election.

With the support of the village aide, Fathoni and his team reached out to those who had campaigned for Surojo during the 2012 village election. Although Surojo had lost the election, he and non-structural PDIP elites had maintained this team and employed it in the 2014 legislative election. Before Ngestiharjo's 2018 election, this group was seeking to field its own candidate. However, unable to find an appropriate candidate, the group chose to accept Fathoni's advances.

Fathoni reached out to Surojo's former campaign team through his brother, who had studied together with one of the team's key figures. Fathoni sought to capitalise upon the team's experience with the 2012 village election and 2014 legislative election, as well the team leader's popularity and respect. ${ }^{28}$ The leader of Surojo's team had long facilitated residents' access to healthcare and education services by helping them complete the necessary forms and negotiating with officials (SL, interview, November 1, 2018) ${ }^{29}$

After Fathoni met with the leader of Surojo's team, he soon gained the support of the remainder of the campaign team. They communicated with Surojo, with non-structural PDIP elites, and with other political actors, all of whom agreed to support Fathoni's campaign for village chief. Surojo's allies had two main motivations for supporting Fathoni. First, they shared a single enemy, Oni, who had previously defeated Surojo in the 2012 village chief election,

\footnotetext{
28 Ibid.

29 Interview with a key PDIP figure and cadre in Ngestiharjo.
} 
and as such Surojo's team was more than willing to support Fathoni (the only viable challenger). Second, the former leader of Surojo's campaign team planned to contest the 2019 legislative election, and as such he needed to mobilise and test the political machine. By campaigning for Fathoni, the team could bring down the PurwonoOni dynasty. Third, many former members of Surojo's campaign team lived in poverty, without any formal source of income. They hoped that, after Fathoni was elected, team members would become involved in the management of village enterprises. ${ }^{30}$

This alliance of convenience united former opponents: the Surojo campaign team and the political machine. Shortly before the election, they held a joint forum to determine their shared goals and mechanisms. During this forum, the owner of the political machine admitted to all attendees that he and his team had cheated during the 2002 and 2012 elections. He apologies to Surojo and his team, and admitted that he regretted backing Purwono and Oni during their electoral campaigns. Fathoni, sitting next to a young man from the United Development Party (Partai Persatuan Pembangunan, PPP) who had the ear of the party's legislative candidate, also heard these confessions.

At this forum, attendees agreed how their campaign team should be managed as well as the mechanisms it should use. First, they agreed that the owner of the political machine would lead Fathoni's campaign team and fund most of his political expenses (although no amount was specified). Second, they agreed that the PPP cadre with whom Fathoni was sitting would serve as team secretary. This was Fathoni's own request; he knew the young man well through his activities in the village, and recognised that the man's previous campaign experience ${ }^{31}$ would benefit him. Fathoni also believed that this man would be a loyal ally, as well as an

$30 \quad$ Ibid.

31 During the 2014 legislative elections, this young man had managed the candidate's schedule and other technical matters (arranging meetings, making invitations, etc.). 
objective voice, being unaffiliated with the political machine and Surojo (Fathoni Aribowo, interview, October 30, 2018).

Third, a member of Surojo's former campaign team was chosen as field coordinator and tasked with handling campaign activities such as rallies and convoys, as well as distributing food and remunerating witnesses for their services. Although campaign decisions were made by the owner of the political machine, members of Surojo's former campaign team recommended numerous strategies that were ultimately implemented. By using one of Surojo's former campaign team members as his field coordinator, Fathoni was able to prevent the political machine from intervening in his campaign activities. Fourth, the team decided to establish two command posts, one north of Wates Road (at Fathoni's home) and one south of Wates Road (at the home of the owner of the political machine). Ngestiharjo is divided into two parts by Wates Road, which links Yogyakarta City with the ring road and with outer territories. By establishing two command posts, Fathoni's team was able to campaign efficiently and effectively. Some pedukuhan could be more effectively reached through the political machine, while others could only be efficiently reached by former members of Surojo's campaign team.

Over the course of the campaign, several village administrators-including the chairman of the elections commission - supported Oni, as seen by their willingness to extend the registration period and by their campaigning for the incumbent in several parts of the village (SL, interview, November 1, 2018). ${ }^{32}$ Considering this detrimental to his own campaign, Fathoni asked the former members of Surojo's campaign team to arrange a meeting with Suharsono, the Regent of Bantul. Having been backed in the 2015 Bantul election by Gerindra, Suharsono was known to be close to the non-structural PDIP elites. It was even rumoured that he had previously been a PDIP member, but chosen to leave

32 Interview with a key PDIP figure and cadre in Ngestiharjo. 
the party after his advancement was blocked by former regent Idam Samawi. Following the 2015 Bantul election, PDIP cadres at the grassroots were polarised, with some supporting Sri Suryawidati (the party's official candidate) and others backing Suharsono. Those who supported Suharsono's candidacy, including Surojo's former campaign team, termed themselves "the red vest volunteers" (relawan Jas Merah), and Suharsono maintained close ties with them even after being elected.

Fathoni met Suharsono at Paramsamya, the government offices of Bantul Regency, where he was accompanied by former members of Surojo's campaign team. Fathoni told the regent how the incumbent had been manipulating the village administration to advance her campaign interests. Not long after meeting with Fathoni, Suharsono, through Circular of the Regent of Bantul No. 141/04386/Pemdes regarding the Neutrality of Village Government Officials and the Mechanisms of the 2018 Simultaneous Village Chief Elections, set sanctions for village officials who failed to act neutrally. This circular was distributed to village chiefs and village advisory councils across Bantul. Afterwards, Suharsono-who was serving as the chairman of Gerindra's Bantul Office-instructed the party's Ngestiharjo branch to support Fathoni in his electoral campaign. ${ }^{33}$

Five other parties supported Fathoni's campaign, namely the Prosperous Justice Party (Partai Keadilan Sejahtera, PKS), Nasdem, National Mandate Party (Partai Amanat Nasional, PAN), United Development Party (Partai Persatuan Pembangunan, PPP), and the Demokrat. These parties' support was heavily rooted in their own political interests, particularly their desire to field a candidate in the 2019 legislative election. These political parties sought to gather voter support for Fathoni, with their activities funded by their potential legislative candidates. In return, these parties expected Fathoni to support their candidates during the 2019 legislative 
election. Fathoni prepared a list of candidates and the extent they had contributed to his campaign, giving him a record that he could consult when choosing which candidate to support. Several legislative hopefuls provided significant material and immaterial contributions, including not only the former leader of Surojo's campaign team (who was a member of Fathoni's team), but also the PPP candidate (who contributed large banners to the campaign) and the PKS candidate (who provided modules for monitoring and securing votes at ballot boxes) (Fathoni Aribowo, interview, October 30, 2018).

Fathoni's broad support could be attributed to these parties' perception of a shared enemy, PDIP, as represented by Purwono and Oni. For decades, PDIP had dominated the political processes in Ngestiharjo; during the 2014 legislative election, for example, PDIP's candidate Purwono received more than 10,000 votes. These parties hoped that, by defeating Oni in the village election, they would gain enough ground to win the 2019 legislative election.

From the beginning of his campaign, Fathoni had sought the support of a range of parties, and indeed one of his campaign promises was to transform Ngestiharjo into a "beautiful rainbow" where banners of all colours could hange ${ }^{34}$ Fathoni also hoped that, by casting his net wide, he could receive the financial and political support needed to develop the village. Fathoni recognised that, if he were to rely solely on funding from the central and local government, Ngestiharjo would never achieve its development goals and his plans could never be realised.

To prepare his strategies and formulate his vision and mission, Fathoni sought the assistance of a local academic. He wanted somebody who was capable of translating his ideas into clear vision and mission statements that voters would understand and approve. Fathoni was introduced to this academic by a village youth, who studied under him. The challenger desired an inspiring vision and 
mission, rather than a normative one that espoused nothing more than the fulfilment of administrative obligations or mirrored existing statements. Fathoni hoped that his vision and mission would attract voters, persuade them to support him and his political programmes (FG, interview, September 28, 2018). ${ }^{35}$

Fathoni socialised his vision, mission, and programmes through direct interactions with the local community. Every day, he held three or four meetings with different social groups; each meeting was attended by 50 to 60 people, for whom Fathoni had to provide snacks and drinks. These meetings were scheduled by the team secretary, with the assistance of field coordinators at the pedukuhan level. During these meetings, Fathoni did not only present his vision, mission, and programmes. He also emphasised the danger of money politics, underscored that current law prohibited palagara, promised to put an end to extortion, and informed audiences that the incumbent was under investigation for corruption (DK, interview, October 10, 2019). ${ }^{36}$

Fathoni's campaign team also spread his vision, mission, and programmes, as well as rumours about the incumbent, through social media applications and chat programmes such as WhatsApp. Although all of this digital information had to be seen by the field coordinator and approved by Fathoni and the owner of the political machine, its distribution was coordinated by the village youths, most of whom were members of the Karang Taruna Youth Group, which solidly backed Fathoni (LK, interview, October 2, 2018). ${ }^{37}$ Information was also distributed visually through memes, which helped voters better understand their message. Several of these campaign messages went viral among the local community, being shared and discussed for days afterwards.

The owner of the political machine deliberately included

\footnotetext{
35 Interview with an academic in Ngestiharjo.

36 Interview with the secretary of the Fathoni Aribowo Campaign Team.

37 Interview with youth figure and administrator.
} 
the village youths and local strongmen in campaign activities. He had spent decades working with these youths, provided them with funding, and established close personal relationships with them. The youths respected him greatly and considered him a pillar of the local community. As such, he used their quantity and fervour to put pressure on his opponent. During the three days of open campaigning, the owner of the political machine spent a significant amount of money to mobilise volunteers. He printed 1,200 shirts for his volunteers, and provided them with food, cigarettes, and money; for the volunteers at the southern command post, he even provided alcohol (Fathoni Aribowo, interview, October 30, 2018). Fathoni, meanwhile, was responsible for the northern command post, and as such financially responsible for volunteers' transportation, food, and cigarettes. These command posts, each of which coordinated some 600 to 1000 youths, differed only in their provision of alcohol; Fathoni refused to serve alcohol at his home, and required volunteers to travel to the southern command post if they wanted alcohol (CS, interview, 31 October 2018). ${ }^{38}$

\section{The Power of the Challenger and the Political Machine}

Fathoni's electoral victory was integrally linked to the skill with which he managed the political machine and his own socio-political networks. He was the central node linking the political machine with other political actors. He also exploited the past enmity of the owner of the political machine and his former opponents, seeing it as an opportunity to exert control over his campaign team. Although the owner of the political machine was the leader of his campaign team and his greatest financial supporter, Fathoni retained a central role in team activities, even refusing to allow the owner of the political machine to interact with other political actors unless he was present.

This opportunity was recognised by the owner of the political

38 Interview with the owner of the political machine. 
machine, who perpetuated it through the dual command post system. Fathoni's own allies usually met at the northern command post (i.e. at Fathoni's home); only rarely would they travel to the southern command post, and when they did, Fathoni was sure to be there. Meanwhile, the owner of the political machine did not attend or become involved in the team's internal meetings, being both unable to penetrate Fathoni's own networks and busy managing his own political machine. Rather, the owner of the political machine was expected to simply validate the results of their meetings in his official capacity as campaign leader. On several occasions, Fathoni held closed meetings with his socio-political allies, including the former members of Surojo's campaign team, party cadres, and academics. Fathoni sought to retain control of these networks.

Fathoni's skill managing the political machine and his sociopolitical networks was supported by his own personal wealth, which included assets nearly equivalent to those of the owner of the political machine. The creation of two command posts required a different approach to funding, with the expenses of the northern post being borne by Fathoni and the expenses of the southern post being borne by the owner of the political machine. During the two weeks before and after the election, Fathoni provided food, drinks, and cigarettes to all supporters and voters who visited his northern command post. Fathoni's wife, as well as the neighbourhood women, prepared and served this food. This also occurred at the southern command post, with one key difference: alcohol was available to members of the political machine and the campaign team, many of whom were youths or local strongmen.

Funding was not only used for operational matters, but also for campaign activities. Fathoni personally paid for the printing of banners, covered transportation costs, and paid electoral witnesses. By doing so, he avoided becoming overly indebted to the owner of the political machine, and thus prevented his ally from interfering in his post-electoral duties as village chief.

Owing to Fathoni's power and central position, both within 
his campaign team and within his socio-political networks, the owner of the political machine could no longer use the dishonest, undemocratic, and clientelistic approaches he had employed in previous elections. Not only was the owner of the political machine limited by his resources, but he was not the dominant actor in the campaign team. Fathoni's expenditures equalled his own, while Fathoni's socio-political networks were just as involved in campaigning as the political machine; indeed, the members of Surojo's former campaign team threatened to withdraw their support if they saw evidence of dishonest and clientelistic campaign activities. The owner of the political machine, who had been the primary driver of dishonest electoral practices, knew exactly what parts of the village were vulnerable to outside influences; as such, he urged local youths and strongmen to monitor these locations and report any suspected cases of electoral fraud. Ultimately, there were no reported cases of vote buying.

The ability of individual candidates to prevent vote buying and clientelistic practices has been noted in several elections, but most commonly in supra-village elections. For example, Hasto Wardoyo was able to win Kulon Progo's 2017 election without buying votes, relying instead on his popularity and his successful implementation of programmatic policies. By improving the quality of public services, he was able to ensure that the poor received education, health, and financial services; with their needs met, voters were less likely to sell their votes.

Fathoni, however, was not an incumbent. Instead, he rose to prominence because of his managerial abilities and the incumbent's poor performance. Despite his campaign team representing a range of diverse interests, Fathoni was an effective coordinator, and his team outperformed the PDIP's established political machine. Furthermore, he exploited the general dissatisfaction with the incumbent's performance and provision of services, arguing that his own vision, mission, and programmes would promote better public services. For her part, the incumbent was unable to provide 
evidence of her professional achievements. During the three days of open campaigning, Oni only voiced her own vision and mission; she neglected to challenge Fathoni's narrative and framing of her administration.

Even with these dynamics, Ngestiharjo's 2018 village election was a close one, with a margin of only 281 votes. Although Fathoni had rapidly mobilised his political allies, reaching out to diverse political actors and uniting them against a shared enemy. Fathoni positioned himself as able to redress the wrongs of the past administration and to rebuild public trust in the government, and as such he increased his own popularity and electability. At the same time, he avoided clientelistic practices such as vote buying, relying on programmatic policies and campaign promises. In this manner, he was able to maintain strong socio-political networks and retain voter trust.

\section{Conclusion}

This article has used the 2018 village election in Ngestiharjo, Yogyakarta, to show that electoral contenders can win elections and use political machines without transactionalism or clientelism. The author has explored the factors that distinguished the political machine used in Ngestiharjo's 2018 election from the standard typology, and confirmed that local contexts and village-level political dynamics significantly influence how political machines function. In the case of Ngestiharjo, four factors-elite fragmentation, candidate recruitment, socio-political networks, and a shared enemy-effectively negated the need to buy public services and use clientelistic strategies.

Through interviews, the author has confirmed that the owner of the political machine-despite having previously backed the incumbent and being part of the village elite-chose to switch allegiances and support the challenger. Indeed, the very candidacy of this challenger was rooted in the owner of the political machine's 
desire to defeat the incumbent. The author has also shown that the challenger activated his socio-political network and incorporated it into the political machine, uniting diverse interest groups in their desire to challenge the incumbent and her dynasty. At the same time, the candidate used his socio-political networks to protect himself from excessive intervention. His strong bargaining power, as well as his socio-political networks outside the political machine itself, enabled the challenger to avoid the previously common practice of clientelism. This clientelism was further eroded by the political machine being built upon on social bonds rather than economic transactions.

This author is certain that these findings can contribute significantly to studies of political machines. The case of Ngestiharjo shows that local candidates and political dynamics shape the political machine, determining whether it relies on transactionalism and clientelism or avoids such practices. In Indonesia's village chief elections, political machines are omni-present, given that political parties are prohibited from playing a formal role. Clientelistic political machines should be avoided, as they are detrimental to the culture and the structure of village society. To avoid clientelism, we must do more than simply refine existing electoral mechanisms; we must also increase the public's involvement in monitoring elections. 


\section{References}

Ansolabehere, S., \& Snyder, J. (2002). The incumbency advantage in U.S. elections: An analysis of state and federal offices, 1942-2000. Election Law Journal: Rules, Politics, and Policy, 1(3), 315-338.

Aspinall, E., \& As'ad, M.U. (2015). The patronage patchwork: Village brokerage networks and the power of the state in an Indonesian election. Bijdragen Tot De Taal-, Land- En Volkenkunde, 171(2/3), 165-195.

Aspinall, E., \& Rohman, N. (2017). Village head elections in Java: Money politics and brokerage in the remaking of Indonesia's rural elite. Journal of Southeast Asian Studies, 48(1), 31-52.

Aspinall, E., \& Sukmajati, M. (2015). Politik uang di Indonesia: Patronase dan klientilisme pada pemilu legislatif 2014. Yogyakarta: PolGov.

Banfield, E.C., \& Wilson, J.Q. (1966). City politics. Vintage Books: New York.

Bantul, P.D. (2017, August 30). Peraturan daerah kabupaten Bantul nomor 08 tahun 2017 tentang perubahan kedua atas peraturan daerah kabupaten Bantul nomor 03 tahun 2015 tentang tata cara pemilihan, pengangkatan dan pemberhentian lurah desa. Retrieved from hukum.bantulkab. go.id/unduh/peraturan-daerah/2017/08.

Bantul, P. D. (2018). Surat edaran (SE) Bupati Bantul nomor 141/04386/ ad-pemdes tentang netralitas aparatur pemerintahan desa dan tertib pelaksanaan pemilihan kepala desa serentak 2018. 3, October.

Budi, A., Sukmajati, M., \& Prasetyo, W. (2018). Kampanye padat modal oleh calon perseorangan: Studi kasus pilkada kota Madiun 2018. In M. Sukmajati \& A. Perdana (Eds), Pembiayaan Pemilu di Indonesia (pp. 211-328). Jakarta: Bawaslu RI.

Choi, N. (2011). Local politics in Indonesia: Pathways to power. London: Routledge.

Erb, M., \& Sulistiyanto, P. (2009). Deepening democracy in Indonesia? Direct elections for local leaders (Pilkada). Singapore: Institute of Southeast Asian Studies.

Farrell, D. (1996). Campaign strategies and tactics. In L. LeDuc, R. G. Niemi, \& P. Norris (Eds.), Comparing democracies: Elections and voting in global perspective (pp. 160-183). Thousand Oaks, California: SAGE Publications.

Gans-Morse, J., Mazzuca, S., \& Nichter, S. (2013). Varieties of clientelism: Machine politics during elections. American Journal of Political Science, 58(2), 415-432. 
Golosov, G.V. (2013). Machine politics: The concept and its implications for post-soviet studies. Demokratizatsiya: The Journal of Post-Soviet Democratization, 21(4), 459-480.

Gosnell, H.F. (1933). The political party versus the political machine. Sage Journal, 169 (1), 21-28.

Gottfried, A. (1968). Political machines. In D. L. Sills (ed.), International Encyclopedia of the Social Sciences, 12 (pp. 248-252). New York: Macmillan and the Free Press.

Hedman, E. L. (2010). Democratisation \& new voter mobilisation in Southeast Asia: beyond machine politics?: reformism, populism and Philippine elections. London: LSE IDEAS, London School of Economics and Political Science.

Kartodirdjo, S. (1992). Pesta demokrasi di pedesaan: studi kasus pemilihan kepala desa di Jawa Tengah dan DIY. Yogyakarta: Aditya Media.

KPU. (2014). Daftar calon terpilih anggota dprd kabupaten/kota pemilu 2014. Retrieved from http://kpud-bantulkab.go.id/filestorage/ dokumen/2014/09/MODEL\%20EB-3.pdf.

KPU. (2015). Hasil hitung TPS (Form c1) Kabupaten Bantul. Retrieved from https://pilkada2015.kpu.go.id/bantulkab/.

Krebs, T. B. (1998). The determinants of candidates' vote share and advantages of incumbency in city council elections. American Journal of Political Science, 42(3), 921-935.

Krebs, T.B. (2005). Money and machine politics: an analysis of corporate and labor contributions in Chicago city council elections. Urban Affairs Review, 41(1), 47-64.

Lombard, D. (1996). Nusa Jawa silang budaya. Jakarta: Gramedia Pustaka Utama.

Masudi, W. \& Kurniawan, N. I. (2017). Programmatic politics and voter preferences: the 2017 election in Kulon Progo, Yogyakarta. Contemporary Southeast Asia, 39(3), 449-469.

Ngestiharjo, P. D. (2017). Anggaran pendapatan dan belanja desa (APBDes) Ngestiharjo 2017. Yogyakarta: Ngestiharjo Village Government.

Stokes, S.C. (2005). Perverse accountability: A formal model of machine politics with evidence from Argentina. American Political Science Review, 99(3), 315-325.

Szwarcberg, M. (2015). Mobilizing poor voters: Machine politics, clientelism, and social networks in Argentina. Cambridge: Cambridge University Press.

Trounstine, J. (2011). Evidence of a local incumbency advantage. Legislative 
Studies Quarterly, 36(2), 255-280.

Yuningsih, N.Y., \& Subekti, V. S. (2016). Demokrasi dalam pemilihan kepala desa? Studi kasus desa dengan tipologi tradisional, transisional, dan modern di provinsi Jawa Barat tahun 2008-2013. Jurnal Politik, 1(2), 231-261. 